\title{
Expression of ADAMTS13 and PCNA in the Placentas of Gestational Diabetic Mothers
}

\author{
Expresión de ADAMTS13 y PCNA en las Placentas de Madres Diabéticas Gestacionales
}

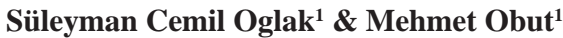

OGLAK, S. C. \& OBUT, M. Expression of ADAMTS13 and PCNA in the placentas of gestational diabetic mothers. Int. J. Morphol., 39(1):38-44, 2021.

SUMMARY: GDM is linked with overexpression of inflammatory cytokines and increased oxidative stress, leading to endothelial dysfunction and vascular disorder. Weaimed to examine the expression of ADAMTS13 and PCNA in the placentas of gestational diabetes mellitus (GDM) patients to investigate the effects of hypoxia, induced by GDM, on proliferation and extracellular matrix formation in the maternal and fetal placenta cells. A total of 60 placentas were collected from pregnant women admitted to the obstetrics clinic. Thirty of them were diagnosed with GDM, and 30 of them were diagnosed with non-GDM patients. Samples were fixed in $10 \%$ formaldehyde, after routine follow-up, embedded in paraffin wax. Sections of $5 \mu \mathrm{m}$ were cut stained with Mayer Hematoxylin-Eosin, examined under a light microscope. Sections for immunohistochemical analysis were cut and processed for antigen retrievalin citrate solution. Sections were incubated with ADAMTS13 and PCNA primary antibodies, counterstained with hematoxylin, and evaluate under a light microscope. In histopathological examination, the non-diabetic placentas showed that decidua cells in the maternal region were polygonal with oval nuclei and organized in groups. In the GDM group, there were pyknosis and apoptotic changes in decidua cell nuclei. Vacuolar areas were observed in large cavities in maternal connective tissue. Inflammation and dilatation with congestion were observed in the blood vessels of the villus. In the GDM group, positive ADAMTS13 expression was observed in the decidua cells vascular endothelial cells, and surrounding connective tissue fibroblast cells. In the GDM group, a significant increase in PCNA expression was observed in decidua cells, connective tissue cells and endothelial cells. Functional changes in ADAMTS13 proteases and PCNA were thought to induce maternal and fetal complications by stimulating extracellular matrix development.

KEY WORDS: Gestational diabetes mellitus, ADAMTS13, PCNA

\section{INTRODUCTION}

Gestational diabetes mellitus (GDM) is one of the most critical gestation complications affecting $7 \%$ of all pregnancies. GDM is defined as any glucose intolerance with the onset or first recognition during gestation can be diagnosed with a glucose tolerance test during gestation. Hyperglycemia is characterized by several degrees of maternal (cesarean delivery, future diabetes, maternal death) and fetal (premature birth, macrosomia, neonatal morbidity, perinatal mortality) complications (Shaat \& Groop, 2007).

GDM is linked with overexpression of inflammatory cytokines and increased oxidative stress, leading to endothelial dysfunction and vascular disorder (Di Fulvio et al., 2014). GDM pregnancies carry high risk and require close maternal and fetal follow-up. GDM can cause morbidity and mortality such as polyhydramnios, intrauterine growth restriction, fetal hypoxia, fetal macrosomia with traumatic vaginal delivery, insufficient nursing, maternal/ fetal hyperglycemia (Crowther et al., 2005). Morphological examinations of GDM placentas have shown structural alterations in the syncytiotrophoblasts, cytotrophoblasts, trophoblastic basement membrane, and fetal vessels (Honda et al., 1992).

A Disintegrin and Metalloproteinase with Thrombospondin motifs (ADAMTS) proteases are expressed in many tissues beginning from the development of the embryo. They are involved in many processes, including restructuring the extracellular matrix, remodeling tissue, angiogenesis, organogenesis, and invasion of tumor cells (Kelwick et al., 2015). Disintegrin or cysteine-rich domain in ADAMTS family members have been shown to regulate migration and cell adhesion. The active metalloproteinase domain has been reported to disrupt extracellular matrix 
components, thereby promoting cell proliferation, cell migration, and angiogenesis by inducing the secretion of cytokines and growth factors (Martin et al., 2015; Ota et al., 2016). ADAMTS13 performs an essential role in regulating thrombosis and hemostasis by cleaving the von Willebrand factor (VWF) (Dong et al., 2002). ADAMTS13 mRNA was detected in human placentas (Plaimauer et al., 2002). Once a cell undergoes apoptosis, its chromatin begins to condense, and its size begins to shrink. Later the cell divides into smaller apoptotic bodies. Fragmented nuclei and all structures of the cell are eliminated.

Proliferative cell nuclear antigen (PCNA) is a marker for the cell cycle. Although PCNA is an accessory protein required for DNA synthesis, its deficiency prevents cell division (Jónsson \& Hübscher, 1997). Besides DNA replication, PCNA is also related tochromatin modification, DNA repair, sister-chromatid adhesion, and cell cycle control (Maga \& Hubscher, 2003). In their study, Acar et al. (2008) reported that PCNA immunopositive cell frequency decreased in diabetic rat placentas and the control group. In another study, it was observed that the number of PCNA immunopositive cells in the placenta decreased in parallel with the gestational age. These findings support that the placenta loses its proliferative character as it approaches term (Maruo et al., 2001).

In this study, we aimed to examine the expression of ADAMTS13 and PCNA in the placentas of gestational diabetes mellitus (GDM) patients to investigate the effects of hypoxia, induced by GDM, on proliferation and extracellular matrix formation in the maternal and fetal placenta cells.

\section{MATERIAL AND METHOD}

The study protocol was approved by the Health Sciences University Diyarbakır Gazi Yas, argil Training and Research Hospital Ethical Committee, and all patients signed an informed consent form. A total of 60 placentas were collected from pregnant women who were admitted to the obstetrics clinic. Only placentas between 28-38 weeks of gestation were included. These placental tissues were obtained from non-diabetic and diabetic pregnancies immediately after cesarean section.

The groups were assigned 30placentas of GDM patients and 30placentas of non-diabetic patients. A fasting plasma glucose $>126 \mathrm{mg} / \mathrm{dl}$ is diagnostic of overt diabetes. GDM was diagnosed with $75 \mathrm{~g}$ oral glucose tolerance test (OGTT) venous plasma/serum threshold values as follows: Fasting 92mg/dl, 1 hour $180 \mathrm{mg} / \mathrm{dl}, 2$ hours $153 \mathrm{mg} / \mathrm{dl}$. The test was performed after a fasting period of 8 to 14 hours in the morning. Patients experienced the OGTT after three days of unlimited physical activity and free diet (>150 grams carbohydrates per day). One or more of the test's values must be equaled or exceeded for the diagnosis of GDM (Committee on Practice Bulletins-Obstetrics, 2018). Patients with health conditions related to intrauterine hypoxia (smoking, preeclampsia, maternal obesity, anemia, advanced maternal age, inflammatory diseases during pregnancy, infections, and asthma) were excluded.

Histopathological examination. Placental parts were fixed in $10 \%$ formaldehyde, followed by washing, dehydration, clearing in xylene and incubated at $58{ }^{\circ} \mathrm{C}$ in paraffin wax. Five $\mathrm{mm}$ sections were taken from paraffin blocks, and sections were transported to distilled water through deparaffinization and descending alcohol series. We stained the sections with Mayer Hematoxylin-Eosin and mounted with Entellan ${ }^{\mathrm{TM}}$. Zeiss Imager A-2 Axio (Germany) light microscope was used for the evaluation of the tissue sections.

Immunohistochemical examination. Five $\mu \mathrm{m}$ sections were taken from paraffin-embedded placenta blocks, then deparaffinized passed through the alcohol series and brought to distilled water. Sections were held in the microwave oven for $3 \times 5 \mathrm{~min}$ in citrate solution for antigen retrieval. After allowing to cool for $10 \mathrm{~min}$ at room temperature, we washed the sections with a phosphate buffer solution (PBS). They were then treated with $3 \%$ hydrogen peroxide $(\mathrm{H} 2 \mathrm{O} 2)$ for 10 minutes. Samples were rinsed in distilled water and washed with PBS (pH 7.6). Then, we incubated the sections with mouse monoclonal anti-CD44 antibody (Santa Cruz, 1:100) and mouse monoclonal anti-PCNA antibody (Santa Cruz, 1:100). Washing three times in PBS, secondary antibody solution (Biotinylated Goat Anti-Mouse, LabVision) was dropped on slides for 10 minutes. The streptavidin peroxidase solution (Streptavidin Peroxidase, LabVision) was used in the sections for 15 minutes. After washing with PBS, a 3-amino-9-ethylcarbazole (AEC) chromogen solution was applied to slides for 8 minutes. The sections were washed with distilled water and counterstained with hematoxylin for 2 minutes to evaluated under a light microscope (Nikon).

Statistical analysis. Statistical analyses of the data were conducted using IBM SPSS 15.0 for Windows (SPSS Inc., Chicago, IL, USA). Measured variables were presented as mean \pm standard deviation. Shapiro-Wilk tests were used to determine whether the numerical data matched the normality distribution. The independent t-test was used to compare the normally distributed data. We used the Mann-Whitney U test to compare the non-normally distributed data. A P-value of less than 0.05 was accepted as statistically significant. 


\section{RESULTS}

The demographic characteristics and laboratory values of the patients were shown in Table I. There were no statistically significant differences between the two groups in terms of age, gravidity, parity, blood pressure, hemoglobin, platelets, urea, creatinine, ALT, and AST values. Plasma glucose and HbA1c levels were significantly higher in the GDM group than in the control group $(\mathrm{p}<0.001)$.

The histopathological and immunohistochemical parameters of the GDM patients and non-GDM patients were compared in Table II. When the histopathological findings were compared between the GDM and the control groups, there was an increase in Sinsistialknots, congestion in blood vessels, fibrinoid accumulation, and inflammation in the GDM group than those of the control group $(\mathrm{p}<0.001)$. Also, there was an increase in expression of ADAMTS13 and PCNA in the GDM groupcompared to the control group $(\mathrm{p}<0.001)$.

In histopathological examination, the non-diabetic placentas showed that decidua cells in the maternal region were polygonal with oval nuclei and organized in groups. In the chorionic villi, the syncytial cells were flat, blood vessels were regular, and connective tissue cells were diffuse
(Fig. 1). In the GDM group, there were pyknosis and apoptotic changes in decidua cell nuclei. Vacuolar areas were observed in large cavities in maternal connective tissue. There was an increase in the number of syncytial nodes and bridges in the periphery of the root villi. Inflammation and dilatation with congestion were observed in the blood vessels of the villus (Fig. 2). When ADAMTS13 activity was examined in the control group, it was positive in connective tissue fibers and fibroblast cells except for umbilical cord vessels. ADAMTS13 was negatively expressed in decidua cells and trophoblast cells of both root villi and free villi of the maternal region (Fig. 3). In the GDM group, positive ADAMTS13 expression was observed in the decidua cells, vascular endothelial cells, and surrounding connective tissue fibroblast cells. Also, ADAMTS13 expression was positive in Hoffbauer cells, vascular endothelial cells of free villi, and some inflammatory cells (Fig. 4). In the control group, negative PCNA expression was observed in the polygonal decidua cells, connective tissue cells, trophoblast cells, and vascular endothelial cells in the maternal region (Fig. 5). In the GDM group, a significant increase of PCNA expression was observed in decidua cells, connective tissue cells, and endothelial cells (Fig. 6).

Table I. The demographic characteristics and laboratory values of the patients.*

\begin{tabular}{|c|c|c|c|}
\hline & Control $(n=30)$ & GDM $(n=30)$ & P value \\
\hline Age, years & $29.14 \pm 6.32$ & $31.21 \pm 5.67$ & 0.29 \\
\hline Gravidity, $\mathrm{n}$ & $2.94 \pm 1.48$ & $3.47 \pm 1.61$ & 0.32 \\
\hline Parity, n & $1.77 \pm 1.62$ & $1.74 \pm 1.03$ & 0.22 \\
\hline Sistolic Blood Pressure, $\mathrm{mmHg}$ & $114.27 \pm 10.34$ & $110.65 \pm 8.12$ & 0.24 \\
\hline Diastolic Blood Pressure, $\mathrm{mmHg}$ & $71.70 \pm 6.46$ & $69.33 \pm 7.09$ & 0.16 \\
\hline Hemoglobin, g/dL & $12.6 \pm 1.12$ & $12.5 \pm 0.93$ & 0.86 \\
\hline Pla telets, $\times 103 / \mu \mathrm{L}$ & $253.76 \pm 68.12$ & $256.51 \pm 68.22$ & 0.65 \\
\hline Glucose, mg/dL & $78.87 \pm 10.58$ & $231.06 \pm 39.36$ & $<0.001$ \\
\hline Urea, mg/dL & $16.12 \pm 4.09$ & $16.73 \pm 3.68$ & 0.46 \\
\hline Creatinine, mg/dL & $0.58 \pm 0.05$ & $0.54 \pm 0.05$ & 0.62 \\
\hline $\mathrm{ALT}, \mathrm{U} / \mathrm{L}$ & $13.10 \pm 5.29$ & $11.06 \pm 4.34$ & 0.78 \\
\hline AST, U/L & $22.19 \pm 11.03$ & $17.12 \pm 5.46$ & 0.14 \\
\hline HbA $1 \mathrm{c}, \%$ & $5.09 \pm 0.36$ & $6.88 \pm 0.74$ & $<0.001$ \\
\hline
\end{tabular}

*: mean \pm standart deviation.

Table II. The histopathological and immunohistochemical parameters of the patients.*

\begin{tabular}{lccc}
\hline & Control $(\mathrm{n}=30)$ & GDM $(\mathrm{n}=30)$ & P value \\
\hline Sinsistial knot & $1.38 \pm 0.53$ & $3.34 \pm 0.61$ & $<\mathbf{0 . 0 0 1}$ \\
Congestion in blood vessels & $0.82 \pm 0.64$ & $3.55 \pm 0.52$ & $<\mathbf{0 . 0 0 1}$ \\
Fibrinoid accumulation & $1.08 \pm 0.63$ & $3.24 \pm 0.76$ & $<\mathbf{0 . 0 0 1}$ \\
Inflammation & $1.22 \pm 0.64$ & $3.06 \pm 0.73$ & $<\mathbf{0 . 0 0 1}$ \\
Pic nosis in decidual cells & $0.74 \pm 0.45$ & $3.14 \pm 0.76$ & $<\mathbf{0 . 0 0 1}$ \\
ADAMTS13 expression & $1.20 \pm 0.74$ & $3.03 \pm 0.62$ & $<\mathbf{0 . 0 0 1}$ \\
PCNA expression & $0.81 \pm 0.58$ & $3.22 \pm 0.84$ & $<\mathbf{0 . 0 0 1}$ \\
\hline
\end{tabular}

*: mean \pm standart deviation. 


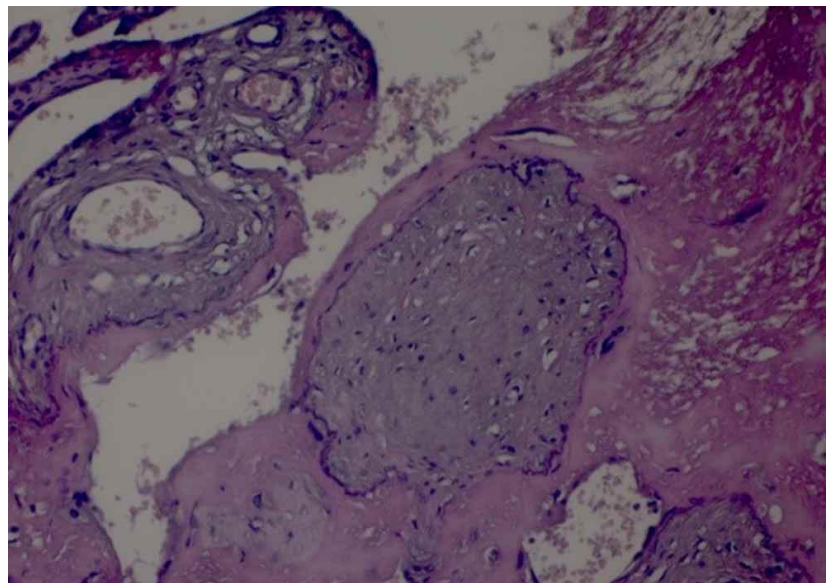

Fig. 1. Control group: Normal appearance in decidua cells, syncytial cells and blood vessels. Hematoxylin an Eosin staining x40.

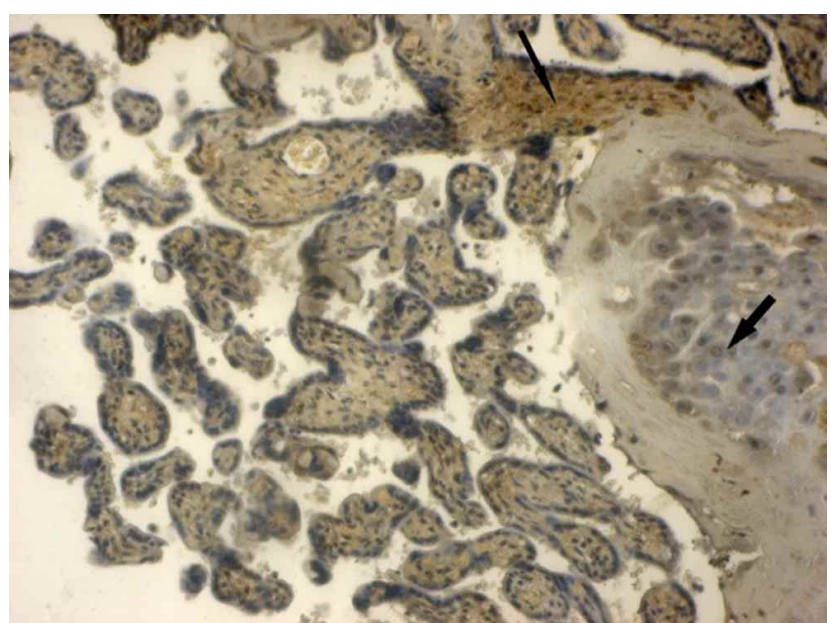

Fig. 3. Control group: positive in connective tissue fibers and fibroblast cells (thin arrow), negative ADAMTS-13 expression in decidua cells (thick arrow) and trophoblast cells of both root villi and free villi of maternal region. ADAMTS13 immun-staining x40.

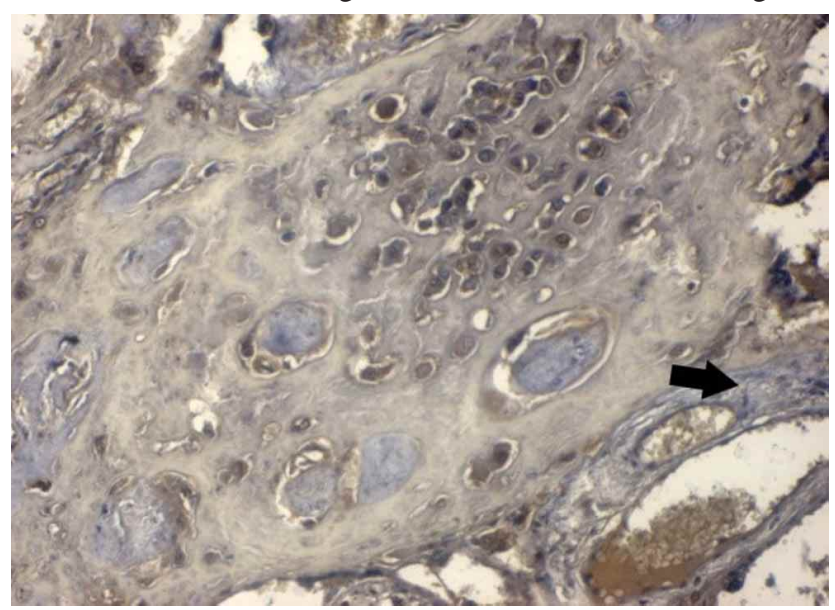

Fig. 5. Control group: Negative PCNA expression in decidua cells (thin arrow), connective tissue cells, trophoblast, and vascular endothelial cells in the maternal region cells (thick arrow). PCNAimmun-staining x40.

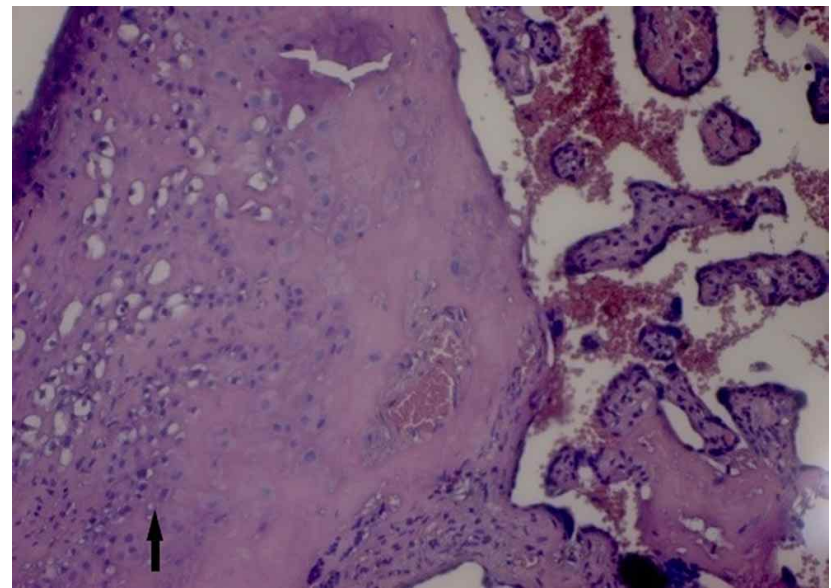

Fig. 2. GDM group: Picnosis and apoptotic changes in decidua cell (thin arrow), an increase in the number of syncytial nodes and bridges of root villi(thick arrow).Hematoxylin-Eosin staining x40.

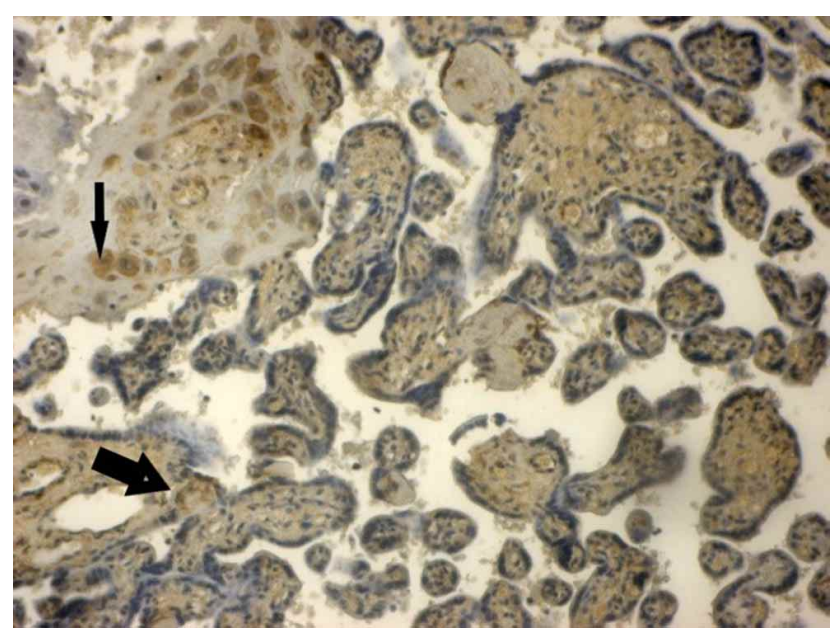

Fig. 4. GDM group: Positive ADAMTS-13 expression in the decidua cells (thin arrow), vascular endothelial cells, and Hofbauer cells (thick arrow). ADAMTS13 immun-staining x40.

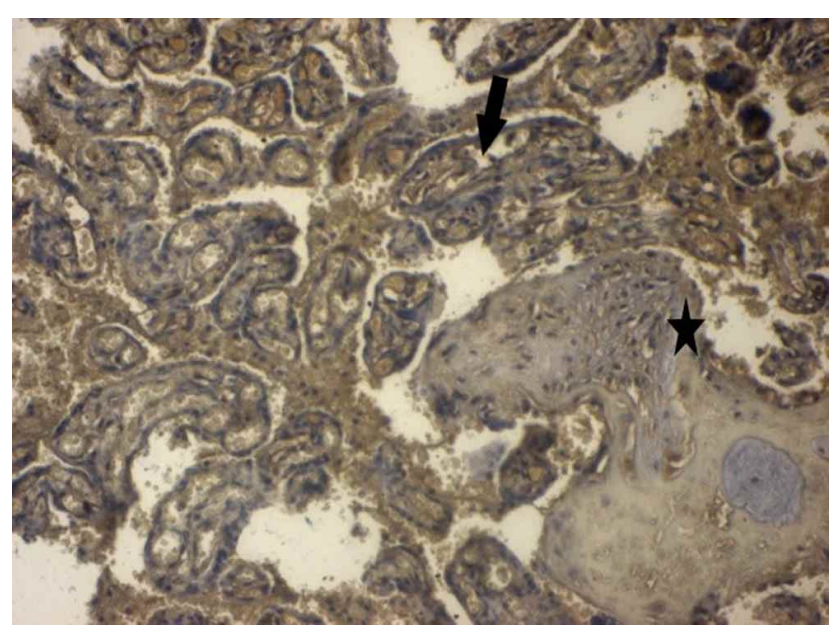

Fig. 6. GDM group: A significant increase of PCNA expression in decidua cells (star), positive PCNA expression connective tissue cells, and endothelial cells (thick arrow). PCNAimmun-staining x40. 


\section{DISCUSSION}

Maternal diabetes induces the development of abnormal fetal organogenesis. Hyperglycemia of the mother directly increases perinatal problems in diabetic pregnant women. Increased glucose in the mother leads to fetal hyperglycemia since it passes to the fetus by facilitated diffusion. Glycogen storage of the placenta in diabetic pregnant women causes decreased glycogen levels in the mother's liver. Insulin resistance in pregnant women causes hyperinsulinemia, hyperglycemia, and hypertriglyceridemia, especially in the last three months (Committee on Practice Bulletins-Obstetrics). In diabetic placentas, there is an increase in the incidence of pathological vascular changes, and these changes are most frequently seen in the blood vessels of the root villi. These lesions affect fetoplacental circulation, blood flow in the degenerated umbilical cord with ischemic histiocytic villitis, and placental infarction. They also trigger syncytial necrosis and perivillous fibrin accumulation with chronic fetal hypoxia. An increased number of chorionic villus branching and syncytial nodes in diabetic pregnancies was reported (Farrar, 2016). It has been suggested that these changes develop as a counter mechanism to fetal hypoxemia to increase the surface where oxygen exchange between the fetus and the mother occurs. In our study, the increased syncytial nodesin chorionic villi, accumulation of necrotic fibrin, congestion in the vessels, and elevated inflammation are significant histopathological findings (Fig. 2).

Brownlee (2001) reported that early intracellular hyperglycemia during diabetes causes abnormalities in blood flow and decreased vasodilator activity, thus leading to increased vasoconstrictor activity. Reduced production of endothelial and neurotrophic factors and excessive accumulation of extracellular matrix contributed to microvascular damage and consequently occluded capillaries.

Trophoblast proliferation induced by free radicals and low oxygen pressure may lead to early preeclampsia. This may be a significant cause of maternal morbidity and mortality (Gosseye \& Fox, 1984). The PCNA protein is one of the central molecules responsible for the cell's life and death of the cell and is involved in DNA repair. Unek et al. (2014) reported that PCNA increased in villous cytotrophoblasts in the preeclampsia group.

Sgarbosa et al. (2006) reported that hyperglycemia might be an essential factor inducing apoptosis in placental trophoblasts and therefore associated with diabetic placenta function. Some authors have also reported that increased placental weight in GDM may be associated with markedly reduced trophoblast apoptosis and apoptosis of villous cytotrophoblast and syncytiotrophoblast nuclei (Magee $e t$ al., 2014). A significant increase in PCNA activity was observed in our study, especially in decidua cells in the GDM group. PCNA expression showed positive reactions in syncytial cells, villous connective tissue cells, and endothelial cells (Fig. 6). This may affect glucose metabolism in decidua cells due to oxygen deficiency and trophoblastic proliferation, so we thought endothelial dysfunction might continue in the late periods of placenta. Although all ADAMTS family member's biological functions are not fully understood, ADAMTS1, 4, and 5 proteins are stated to have the ability to activate the proteolytic modification of extracellular matrix proteins via cell surface proteins (Tang, 2001; Lee et al., 2006). In the last trimester of pregnancy in preeclampsia, ADAMTS proteases play an essential role in rearranging these structures with defective pituitary trophoblast infestation, hypoxic spiral artery formation, and impaired extracellular matrix formation. ADAMTS13 promotes trophoblast cell proliferation, migration, invasion, and tube formation. Placental ADAMTS13 mRNA levels were highest in the first trimester and decreased in the second and third trimesters. These authors have shown significantly lower ADAMTS13 protein levels in placental villi tissues of patients with severe preeclampsia than those in the control group by the western blot method. They thought decreased ADAMTS13 synthesis and secretion in the placentas of patients with severe preeclampsia might be associated with tissue hypoxia and placental ischemia associated with hypertension (Xiao et al., 2017). ADAMTS13 is expressed in the trophoblast and fetal blood vessel endothelium. During pregnancy, the human placenta synthesizes and secretes the active proteolytic ADAMTS13. It is also produced at the highest levels in the first trimester and progressively decreases in the plasma during the second and third trimesters of pregnancy (Feys et al., 2007). Chang \& Yang (2013) showed that the levels of Perlecan increased in the third trimesterin the placentas of pregnant women with GDM. Perlecan is a crucial component of the basement membrane and plays a role in regulating growth factors, extracellular matrix, and angiogenesis.It has been suggested that ADAMTS13 plays a potential role in normal pregnancy and the pathogenesis of pregnancy-related complications. Therefore, it is stated that ADAMTS13 promotes the invasion, migration, proliferation, and network formation of trophoblasts (Xiao et al.). The effect of ADAMTS13 on angiogenesis is essential. In our study's GDM group, ADAMTS13 expression was positive in the maternal decidua cells, vascular endothelial cells, and connective tissue 
fibroblast cells. Also, the expression of ADAMTS-13 was positive in the vascular endothelial cells of free villi, Hoffbauer cells, and some inflammatory cells. With the influence of GDM, it was observed that proteases and proteoglycans like ADAMTS13 cause changes in cells and extracellular matrix structure.

In conclusion, hyperglycemia has been shown to modify the expression of apoptosis-inducing proteins and genes encoding cell proliferation and alter vascular endothelial growth. Functional changes in ADAMTS13 proteases and PCNA were thought to induce maternal and fetal complications by stimulating extracellular matrix development. Further studies are needed at the genetic level to prevent the development of GDM or reduce early and severe maternal and fetal complications associated with hyperglycemia.

OGLAK, S. C. \& OBUT, M. Expresión de ADAMTS13 y PCNA en las placentas de madres diabéticas gestacionales. Int. J. Morphol., 39(1):38-44, 2021.

RESUMEN: La diabetes gestacional está relacionada con la sobreexpresión de citocinas inflamatorias y aumento del estrés oxidativo, lo que lleva a una disfunción endotelial y un trastorno vascular. Nuestro objetivo fue examinar la expresión de ADAMTS13 y PCNA en las placentas con diabetes mellitus gestacional (DMG) para investigar los efectos de la hipoxia inducida por DMG sobre la proliferación y formación de matriz extracelular en células placentarias maternas y fetales. Se recolectaron un total de 60 placentas de mujeres embarazadas ingresadas a la consulta de obstetricia. Treinta de ellas fueron diagnosticadas con DMG y 30 diagnosticadas sin DMG. Las muestras se fijaron en formaldehído al $10 \%$, y luego de un seguimiento de rutina, fueron embebidas en parafina. Se cortaron secciones de $5 \mu \mathrm{m}$ teñidas con hematoxilina-eosina de Mayer, las que fueron examinadas bajo un microscopio óptico. Se cortaron y procesaron las secciones para el análisis inmunohistoquímico para la recuperación de antígeno en solución de citrato. Las secciones se incubaron con anticuerpos primarios ADAMTS13 y PCNA, se contratiñeron con hematoxilina y se evaluaron con un microscopio óptico. En el examen histopatológico, las placentas no diabéticas mostraron que las células de la decidua en la región materna eran poligonales con núcleos ovalados y organizadas en grupos. En el grupo de DMG, se observó picnosis y cambios apoptóticos en los núcleos de las células de la decidua. Se observaron áreas vacuolares en el tejido conectivo materno. En los vasos sanguíneos de las vellosidades se observó inflamación y dilatación con congestión. En el grupo de DMG, se observó expresión positiva de ADAMTS13 en las células de la decidua, en las células endoteliales vasculares y en los fibroblastos del tejido conectivo circundante. En el grupo de DMG se observó un aumento significativo de la expresión de PCNA en células de la decidua, células de tejido conectivo y en las células endoteliales. Se considera que los cambios funcionales en las proteasas ADAMTS13 y PCNA inducen a complicaciones maternas y fetales al estimular el desarrollo de la matriz extracelular.

PALABRAS CLAVE: Diabetes mellitus gestacional; ADAMTS13; PCNA.

\section{REFERENCES}

Acar, N.; Korgun, E. T.; Cayli, S.; Sahin, Z.; Demir, R. \& Ustunel, I. Is there a relationship between PCNA expression and diabetic placental development during pregnancy? Acta Histochem., 110(5):408-17, 2008.

Brownlee, M. Biochemistry and molecular cell biology of diabetic complications. Nature, 414(6865):813-20, 2001.

Chang, S. C. \& Yang, W. C. V. Hyperglycemia induces altered expressions of angiogenesis associated molecules in the trophoblast. Evid. Based Complement. Alternat. Med., 2013:457971, 2013.

Committee on Practice Bulletins-Obstetrics. ACOG Practice Bulletin No. 190: Gestational Diabetes Mellitus. Obstet. Gynecol., 131(2):e49e64, 2018.

Crowther, C. A.; Hiller, J. E.; Moss, J. R.; McPhee, A. J.; Jeffries, W. S.; Robinson, J. S. \& Australian Carbohydrate Intolerance Study in Pregnant Women (ACHOIS) Trial Group. Effect of treatment of gestational diabetes mellitus on pregnancy outcomes. N. Engl. J. Med., 352(24):2477-86, 2005.

Di Fulvio, P.; Pandolfi, A.; Formoso, G.; Di Silvestre, S.; Di Tomo, P.; Giardinelli, A.; De Marco, A.; Di Pietro, N.; Taraborrelli, M.; Sancilio, S.; et al. Features of endothelial dysfunction in umbilical cord vessels of women with gestational diabetes. Nutr. Metab. Cardiovasc. Dis., 24(12):1337-45, 2014

Dong, J. F.; Moake, J. L.; Nolasco, L.; Bernardo, A.; Arceneaux, W.; Shrimpton, C. N.; Schade, A. J.; McIntire, L. V.; Fujikawa, K. \& López, J. A. ADAMTS-13 rapidly cleaves newly secreted ultralarge von Willebrand factor multimers on the endothelial surface under flowing conditions. Blood, 100(12):4033-9, 2002.

Farrar, D. Hyperglycemia in pregnancy: prevalence, impact, and management challenges. Int. J. Womens Health, 8:519-27, 2016.

Feys, H. B.; Canciani, M. T.; Peyvandi, F.; Deckmyn, H.; Vanhoorelbeke, K. \& Mannucci, P. M. ADAMTS13 activity to antigen ratio in physiological and pathological conditions associated with an increased risk of thrombosis. Br. J. Haematol., 138(4):534-40, 2007.

Gosseye, S. \& Fox, H. An immunohistological comparison of the secretory capacity of villous and extravillous trophoblast in the human placenta. Placenta, 5(4):329-47, 1984.

Honda, M.; Toyoda, C.; Nakabayashi, M. \& Omori, Y. Quantitative investigations of placental terminal villi in maternal diabetes mellitus by scanning and transmission electron microscopy. Tohoku J. Exp. Med., 167(4):247-57, 1992.

Jónsson, Z. O. \& Hübscher, U. Proliferating cell nuclear antigen: more than a clamp for DNA polymerases. Bioessays, 19(11):967-75, 1997.

Kelwick, R.; Desanlis, I.; Wheeler, G. N. \& Edwards, D. R. The ADAMTS (A Disintegrin and Metalloproteinase with Thrombospondin motifs) family. Genome Biol., 16(1):113, 2015.

Lee, N. V.; Sato, M.; Annis, D. S.; Loo, J. A.; Wu, L.; Mosher, D. F. \& Iruela-Arispe, M. L. ADAMTS1 mediates the release of antiangiogenic polypeptides from TSP1 and 2. EMBO J., 25(22):5270-83, 2006

Maga, G. \& Hubscher, U. Proliferating cell nuclear antigen (PCNA): a dancer with many partners. J. Cell Sci., 116(Pt. 15):3051-60, 2003.

Magee, T. R.; Ross, M. G.; Wedekind, L.; Desai, M.; Kjos, S. \& Belkacemi, L. Gestational diabetes mellitus alters apoptotic and inflammatory gene expression of trophobasts from human term placenta. J. Diabetes Complications, 28(4):448-59, 2014.

Martin, A. C. B. M.; Cardoso, A. C. F.; Selistre-de-Araujo, H. S. \& Cominetti, M. R. Recombinant disintegrin domain of human ADAM9 inhibits migration and invasion of DU145 prostate tumor cells. Cell Adh. Migr., 9(4):293-9, 2015.

Maruo, T.; Ishihara, N.; Samoto, T.; Murakoshi, H.; Laoag-Fernandez, J. B. \& Matsuo, H. Regulation of human trophoblast proliferation and apoptosis during pregnancy. Early Pregnancy, 5(1):28-9, 2001. 
Ota, M.; Mochizuki, S.; Shimoda, M.; Abe, H.; Miyamae, Y.; Ishii, K.; Kimura, H. \& Okada, Y. ADAM23 is downregulated in side population and suppresses lung metastasis of lung carcinoma cells. Cancer Sci., 107(4):433-43, 2016.

Plaimauer, B.; Zimmermann, K.; Völkel, D.; Antoine, G.; Kerschbaumer, R.; Jenab, P.; Furlan, M.; Gerritsen, H.; Lämmle, B.; Schwarz, H. P.; et al. Cloning, expression, and functional characterization of the von Willebrand factor-cleaving protease (ADAMTS13). Blood, 100(10):3626-32, 2002.

Sgarbosa, F.; Barbisan, L. F.; Brasil, M. A. M.; Costa, E.; Calderon, I. M. P.; Gonçalves, C. R.; Bevilacqua, E. \& Rudge, M. V. C. Changes in apoptosis and $\mathrm{Bcl}-2$ expression in human hyperglycemic, term placental trophoblast. Diabetes Res. Clin. Pract., 73(2):143-9, 2006.

Shaat, N. \& Groop, L. Genetics of gestational diabetes mellitus. Curr. Med. Chem., 14(5):569-83, 2007.

Tang, B. L. ADAMTS: a novel family of extracellular matrix proteases. Int. J. Biochem. Cell Biol., 33(1):33-44, 2001.

Unek, G.; Ozmen, A.; Mendilcioglu, I.; Simsek, M. \& Korgun, E. T. The expression of cell cycle related proteins PCNA, Ki67, p27 and p57 in normal and preeclamptic human placentas. Tissue Cell, 46(3):198-205, 2014.

Xiao, J.; Feng, Y.; Li, X.; Li, W.; Fan, L.; Liu, J; Zeng, X.; Chen, K.; Zhou, X.; Zheng, X. L.; et al. Expression of ADAMTS13 in normal and abnormal placentae and its potential role in angiogenesis and placenta development. Arterioscler. Thromb. Vasc. Biol., 37(9):1748-56, 2017.
Corresponding Author:

Süleyman Cemil Oglak

Department of Obstetrics and Gynecology

Health Sciences

University Diyarbakır

Gazi Yasargil Training and Research Hospital

Diyarbakır

TURKEY

Orcid: 0000-0001-7634-3008

Email: sampson_21@hotmail.com

Received: 08-07-2020

Accepted: 16-09-2020 